\title{
Clustering of Olive Pollens into Model Cultivars on the Basis of Their Allergenic Content
}

\author{
Sonia Morales, Antonio Jesús Castro, \\ Carmen Salmerón, Francisco Manuel Marco, \\ María Isabel Rodríguez-García and Juan de Dios Alché
}

Additional information is available at the end of the chapter

http://dx.doi.org/10.5772/49964

\section{Introduction}

Olive pollen allergy is a leading cause of seasonal allergic disease in the Mediterranean countries, where olive trees are intensively cultivated and pollen grain count reaches very high levels during the pollination season (Wheeler, 1992, Liccardi et al., 1996). The level of sensitization to olive pollen among the general population is directly related to the abundance of trees as this determines allergen exposure. Nevertheless, apart from tree abundance, other factors such as genetic background may influence the incidence of sensitization to olive pollen even in areas of very high exposition (Geller-Bernstein et al. 1996). Olive trees have been cultivated in the Mediterranean basin for several millennia and this has led to the selection of a wide variety of cultivars with agronomic importance. Olive germplasm is exceptionally wide, with more than 250 cultivars only in Spain (Barranco and Rallo, 2005), probably as a direct consequence of intensive cultivation.

Material commonly used for clinical and biological analysis corresponds in most cases to commercially available pollen, obtained from uncertain varietal sources. Previous studies have determined that most allergens isolated and characterized up to date are highly polymorphic (Villalba et al. 1993, 1994; Lombardero et al. 1994; Asturias et al. 1997; Alché et al. 1998; Tejera et al. 1999; Huecas et al. 2001; Martínez et al. 2002; Jiménez-López et al. 2012). Besides polymorphism, olive cultivars display broad differences in the expression levels for many allergens (Carnés et al. 2002; Conde Hernandez et al. 2002; Castro et al. 2003; Morales 2012) as well as in the number and molecular characteristics of the expressed allergen isoforms (Hamman-Khalifa et al. 2003, 2008; Hamman-Khalifa 2005; Castro et al. 2010; Jiménez-López et al. 2012). These differences are in a certain degree 
maintained over the years, and have been demonstrated to be associated to the genetic background of the different olive cultivars (Fernandez Caldas et al. 2007; Morales 2012; Morales et al. this volume). Differences in the allergen composition of the extracts, particularly as regard to the olive pollen major allergen Ole e 1, are responsible of large differences in the biological potency of the extracts. Thus, Castro et al. (2003) analysed the allergenicity and Ole e 1 content in pollen samples of 10 cultivars of olive trees, and compared it to a commercial extract with no indication on varietal origin, probably representing a mixture of several cultivars. The authors found that there are important differences in the content of this major allergen and that Ole e 1 abundance correlated with total allergenicity when extracts were tested by skin prick test (SPT) on allergic patients. Interestingly some patients (about 10\%) did not react with a commercial extract and only reacted to extracts coming from specific cultivars. These findings may have important implications in both diagnosis and therapy of olive pollen allergy, and in the efficacy and safety of the preparations used for specific immunotherapy (SIT) (Castro et al., 2003; Alché et al. 2007; Hamman-Khalifa et al. 2008; Jiménez-López 2008; Morales 2012).

The basis for personalized SIT, based in the individual usage of olive cultivar extracts, have been described and are protected by several Spanish patents (Alché et al. 2005, 2006). However, and as handling and characterization of a large number of cultivar extracts is impracticable under industrial and clinical standards, the present work intends to define a limited number of model cultivar, characterized by distinctive pollen allergen profiles. For this purpose, a number of olive pollen extracts have been analysed in their content for several relevant allergens. After appropriate quantitation, several model cultivars have been defined to group the cultivars analysed. This model can be used as the basis for a future classification and inclusion of the numerous olive cultivars available.

\section{Materials and methods}

\subsection{Pollen samples}

Olea europaea L. pollen samples were obtained during May and June of 2005-2010 from cultivated trees of the following cultivars: 'Picual', 'Manzanilla', 'Arbequina', 'Blanqueta', 'Cornicabra', 'Verdial', 'Lechín', 'Hojiblanca', 'Lucio'and 'Loaime'. Pollen samples were collected from numerous branches of at least two trees of each cultivar by shaking flowering shoots inside paper bags. Prior to its storage in liquid nitrogen, the harvested pollen was sieved through a $150 \mu \mathrm{m}$ mesh in order to eliminate fallen corollas, anthers and other rests. After light microscopy observation, foreign-species pollen was estimated to be $<0.1 \%$ and other plant parts $<0.5 \%$ for all the cultivars used.

\subsection{Preparation of crude protein extracts and SDS-PAGE}

Crude protein extracts were obtained by stirring $1 \mathrm{~g}$ of pollen for each cultivar in $10 \mathrm{ml}$ extraction buffer (0.01 M ammonium bicarbonate, $\mathrm{pH} 8.0$, and $2 \mathrm{mM}$ phenylmethylsulfonyl 
fluoride) for $8 \mathrm{~h}$ at $4^{\circ} \mathrm{C}$. After centrifugation $\left(2 \times 30\right.$ minutes at $14,000 \mathrm{rpm}$ at $\left.4^{\circ} \mathrm{C}\right)$, the supernatants were filtered through a $0.2 \mu \mathrm{m}$ filter, and stored in aliquots at $-20^{\circ} \mathrm{C}$. Protein concentration in the different samples was measured using the Bio-Rad reagent (Bio-Rad, Hercules, CA, USA) and bovine serum albumin (BSA) as standard.

Proteins (30 $\mu \mathrm{g}$ per lane) and Mw1 (New England BioLabs, Ipswich, MA, USA) and Mw2 standards (MBI Fermentas, Vilnius, Lithuania) were separated by sodium dodecyl sulfate-polyacrylamide gel electrophoresis (SDS-PAGE) in $15 \%$ gels in a MiniProtean II system (Bio-Rad). The resulting gels were stained with Coomassie blue. The same procedure described here was applied to a commercially available extract used for olive pollen allergy diagnosis.

\subsection{Immunoblotting}

Gels obtained as described above were transferred onto BioTrace® polyvinylidene difluoride (PVDF) membranes (Pall BioSupport, Port Washington, NY, USA) at $100 \mathrm{~V}$ for 1.5 hours using a Mini Trans-Blot Electrophoretic Transfer Cell (Bio-Rad). Immunoblots were performed independently in the case of Ole e 1 (Figure 2) and Ole e 2 (Figure 3). Ole e 5 and Ole e 9 were simultaneously detected in the same membrane (Figure 4). Prior to the treatment with antibodies, the membranes were blocked with TBST buffer (Tris buffered saline: TBS $+0.3 \% \mathrm{v} / \mathrm{v}$ Tween 20$)+10 \% \mathrm{w} / \mathrm{v}$ dried skimmed milk.

The membranes were probed with antibodies to the following allergenic proteins: Ole e 1, (olive pollen major allergen), Ole e 2 (profilin), Ole e 5 ( $\mathrm{Cu}, \mathrm{Zn}$ superoxide dismutase) and Ole e 9 (1,3- $\beta$-glucanase). The anti-Ole e $1 \mathrm{mAb}$ was kindly provided by Dr. Carlos Lahoz (Fundación Jiménez Díaz, Madrid, Spain) (Lauzurica et al. 1988). The anti-Ole e 2 polyclonal antibody (PoAb) was produced by immunization of rabbits with a keyhole limpet hemocyanin (KLH)-linked synthetic peptide (AQSATFPQFKPEEM) designed from the predicted amino acid sequence of an olive profilin (Ole e 2). Specificity of the antibody was already reported by Western blotting experiments and immunolocalization of the allergen (Morales et al. 2008). The anti-Ole e 9 polyclonal Ab was produced as described above using a synthetic peptide (YPYFAYKNQPTPDT) from the Ole e 9 amino acid sequence (Huecas et al. 2001; Duffort et al. 2006). Finally, we also purchased a commercially available PoAb that recognizes a chloroplastidic isoform of $\mathrm{Cu} / \mathrm{Zn}$-superoxide dismutase (SOD) from Arabidopsis thaliana (Agrisera, city, Sweden, Product No AS06 170), with probed cross-reactivity to Ole e 5 (Zafra 2007).

Primary Abs were diluted in blocking solution and incubated for $2 \mathrm{~h}$ at room temperature, whereas secondary Abs were diluted in TBST buffer and incubated for $1 \mathrm{~h}$ at room temperature in the dark. After Ab incubation, membranes were rinsed in TBST buffer four times for $5 \mathrm{~min}$ each. The different Abs used in this work and their corresponding dilutions are summarized in Table 1. Each experiment described below was repeated in triplicate. Negative controls included preimmune serum in the cases of Ole e 2 and Ole e 9. 


\begin{tabular}{|c|c|c|c|c|}
\hline Target & Primary antibody & Dilution & Secondary antibody & Dilution \\
\hline Ole e 1 & $\begin{array}{l}\text { Mouse anti-olive Ole e } 1 \\
\text { mAb (Lauzurica et al. } \\
\text { 1988) }\end{array}$ & $1: 20,000$ & $\begin{array}{l}\text { Goat anti-mouse IgG Ab, } \\
\text { Alexa fluor 488-conjugated } \\
\text { (Molecular Probes) }\end{array}$ & $1: 10,000$ \\
\hline Ole e 2 & $\begin{array}{l}\text { Rabbit anti-olive Ole e } 2 \\
\text { PoAb } \\
\text { (Morales et al. 2008) }\end{array}$ & $1: 20,000$ & $\begin{array}{l}\text { Donkey anti-rabbit IgG } \\
\text { (Fab fragment) Ab, Cy3- } \\
\text { conjugated (Jackson } \\
\text { ImmunoResearch) }\end{array}$ & $1: 10,000$ \\
\hline Ole e 5 & $\begin{array}{l}\text { Rabbit anti-Cu/Zn SOD } \\
\text { PoAb (Agrisera Prod. } \\
\text { No. AS06 170) }\end{array}$ & $1: 250$ & $\begin{array}{l}\text { Goat anti-rabbit IgG Ab, } \\
\text { Alexa fluor 633-conjugated } \\
\text { (Molecular Probes) }\end{array}$ & $1: 10,000$ \\
\hline $\begin{array}{l}\text { Ole e } 9 \\
\text { (N- domain) }\end{array}$ & $\begin{array}{l}\text { Rabbit anti-olive Ole e } 9 \\
\text { PoAb }\end{array}$ & $1: 10,000$ & $\begin{array}{l}\text { Goat anti-rabbit IgG Ab, } \\
\text { Alexa fluor 633-conjugated } \\
\text { (Molecular Probes) }\end{array}$ & $1: 10,000$ \\
\hline
\end{tabular}

Table 1. Antibodies and dilutions used for immunoblotting experiments. mAb: monoclonal antibody; PoAb: polyclonal antibody.

Imaging was carried out with a Pharos FX Plus Molecular Imager (Bio-Rad) using the Quantity One v4.6.2 software (Bio-Rad).

\subsection{Absolute and relative quantitation of allergens}

The intensity of each fluorescent band was calculated using the quantitation tools of the Quantity One v4.6.2 software. In order to increase sensitivity of measurements and to avoid disturbing factors like the intensity of the background, the presence of individual nonspecific spots, etc., two different methods for quantitation were used:

- For each allergen studied, reactive bands were identified, their optical density individually measured and then their absolute values added for each cultivar. Relative percentages of each allergen were then calculated for each cultivar, taking the cultivar with the highest optical density as the reference, which was assigned $100 \%$.

- Simultaneous measurement of the optical density corresponding to all reactive bands from a given allergen in each cultivar was also performed. As before, relative percentages were also calculated, referred to the cultivar with the highest optical density, which was assigned $100 \%$.

Finally, average of the percentages calculated by both methods was worked out, and the resulting percentages were newly made relative to the cultivar with the highest percentage, which was re-assigned $100 \%$. 


\section{Results}

\subsection{SDS-PAGE protein profiles}

Figure 1 shows the protein profiles of the extracts analysed after SDS-PAGE and Coomassie staining. The patterns observed for the major protein species were somewhat similar for all the cultivars tested. However, clear quantitative differences were distinguished, from which the most conspicuous were those in the protein range of 17-20 kDa. Proteins within this range were relatively abundant in the extracts corresponding to the cvs. 'Picual', 'Manzanilla', 'Cornicabra', 'Hojiblanca', 'Loaime', 'Blanqueta' and 'Lucio'.

When the commercial pollen extract was assayed by SDS-PAGE, a protein profile similar to the profile corresponding to the individual cultivars was observed, although several bands were absent or poorly resolved. Proteins in the range 17-20 kDa represented a low proportion of the total protein for this extract.

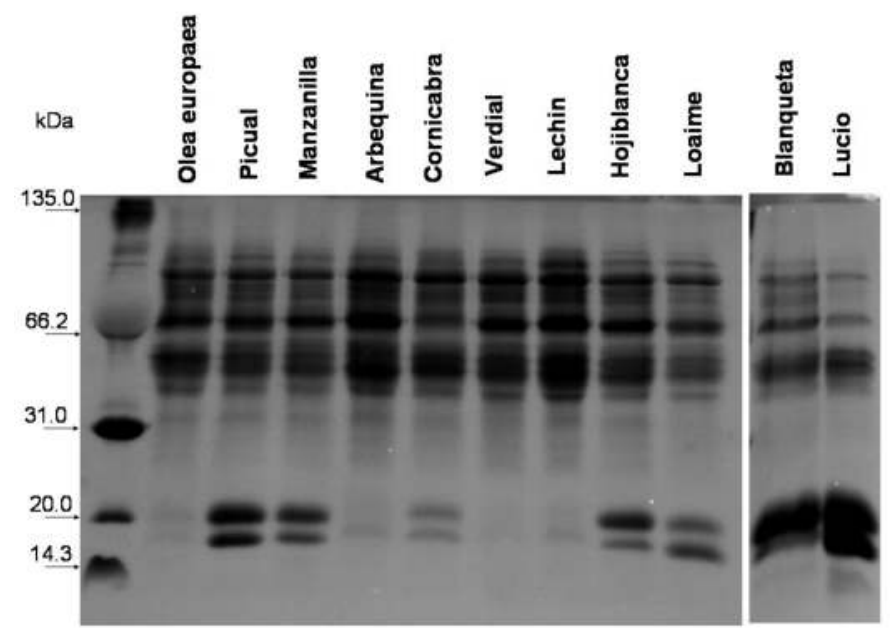

Figure 1. Coomassie stained SDS-PAGE gel of the univarietal pollen extracts and the commercial extract (Olea europaea) after using denaturing, reducing conditions. Gels contained $30 \mu \mathrm{g}$ total protein per lane.

\subsection{Immunoblot detection and quantitation of Ole e 1}

Immunoblots probed with the monoclonal antibody to Ole e 1 resulted in the presence of two major immunoreactive bands of 18 and $20 \mathrm{kDa}$, corresponding to the monomeric nonglycosylated and mono-glycosylated forms (Figure 2). Other immunoreactive bands with low quantitative relevance were observed $(36,40$ y $44 \mathrm{kDa})$ in several lanes.

Bands corresponding to the $\mathrm{Mw}$ of 18 and $20 \mathrm{kDa}$ were quantitated according to the methods described above. Absolute measurements of the intensity of each individual band and both bands simultanously are displayed in Table 2, as well as the relative percentages calculated as described above. 


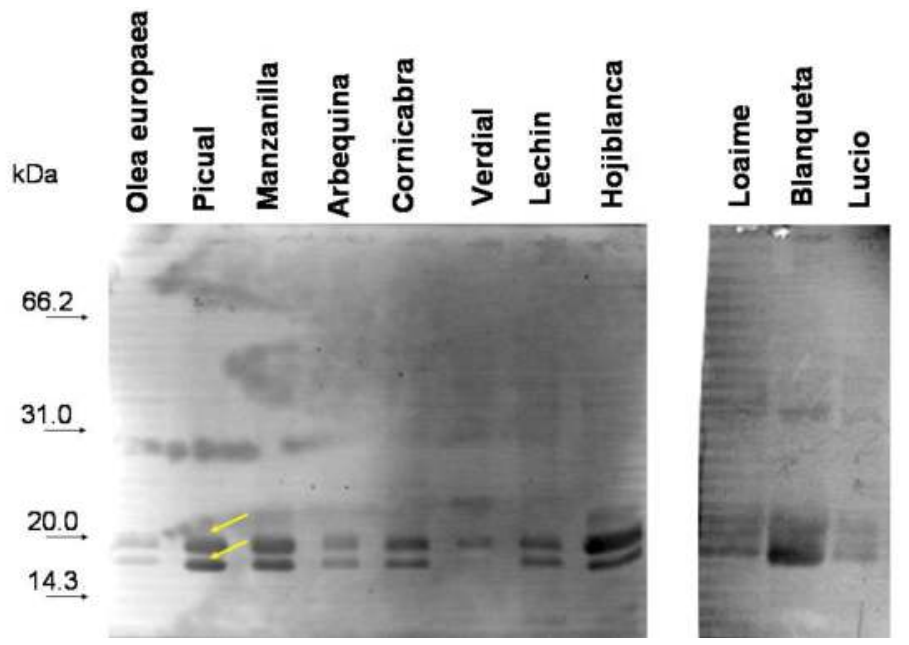

Figure 2. Immunoblot probed with the anti-Ole e 1 monoclonal antibody. Two major bands were observed (yellow arrows), corresponding to apparent molecular weights of 18 and $20 \mathrm{kDa}$.

\begin{tabular}{|c|c|c|c|c|c|c|c|c|c|c|c|}
\hline & 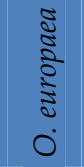 & 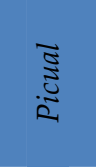 & 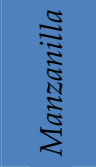 & 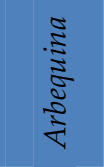 & 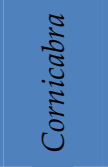 & 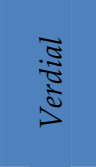 & 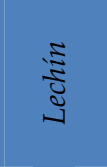 & 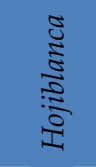 & 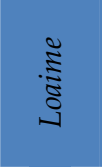 & 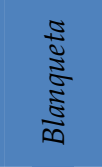 & $\underset{\substack{3 \\
\hdashline}}{8}$ \\
\hline 18 kDa & 3672 & 14385 & 16746 & 11894 & 20033 & 12174 & 17668 & 30706 & 41345 & 40388 & 17436 \\
\hline 20 kDa & 2348 & 10666 & 11233 & 7983 & 11716 & 3204 & 11804 & 22780 & 21143 & 32768 & 13087 \\
\hline $\begin{array}{l}\Sigma 18 \text { and } \\
20 \mathrm{kDa}\end{array}$ & 6021 & 25051 & 27979 & 19877 & 31749 & 15378 & 29472 & 52784 & 62489 & 73156 & 30523 \\
\hline Relative \% & 8.23 & 34.24 & 38.25 & 27.17 & 43.40 & 21.02 & 40.28 & 72.15 & 85.41 & 100 & 41.72 \\
\hline 18 and $20 \mathrm{kDa}$ & 6659 & 26741 & 29626 & 22044 & 34260 & 20950 & 32493 & 54095 & 60906 & 73900 & 30345 \\
\hline Relative \% & 9.01 & 36.18 & 40.09 & 29.83 & 46.36 & 28.35 & 43.97 & 73.21 & 82.42 & 100 & 41.06 \\
\hline $\begin{array}{l}\text { Average } \\
\text { relative \% }\end{array}$ & 8.62 & 35.21 & 39.17 & 28.5 & 41.88 & 24.68 & 42.125 & 72.68 & 83.915 & 100 & 41.39 \\
\hline
\end{tabular}

Table 2. Quantitation of the two major bands cross-reactive to the anti Ole e 1 antibody. Absolute data in volume units $\left(\mathrm{INT}^{*} \mathrm{~mm}^{2}\right)$.

\subsection{Immunoblot detection and quantitation of Ole e 2}

Immunoblots probed with the polyclonal antiserum to Ole e 2 resulted in the presence of up to five major immunoreactive bands of c.a. 14, 13.7, 14.2, 14.9 and $15.7 \mathrm{kDa}$ (Figure 3).

Bands corresponding to the five Mws were quantitated according to the methods described above. Absolute measurements of the intensity of each individual band and all five bands simultanously are displayed in Table 3 , as well as the relative percentages calculated as described above. 


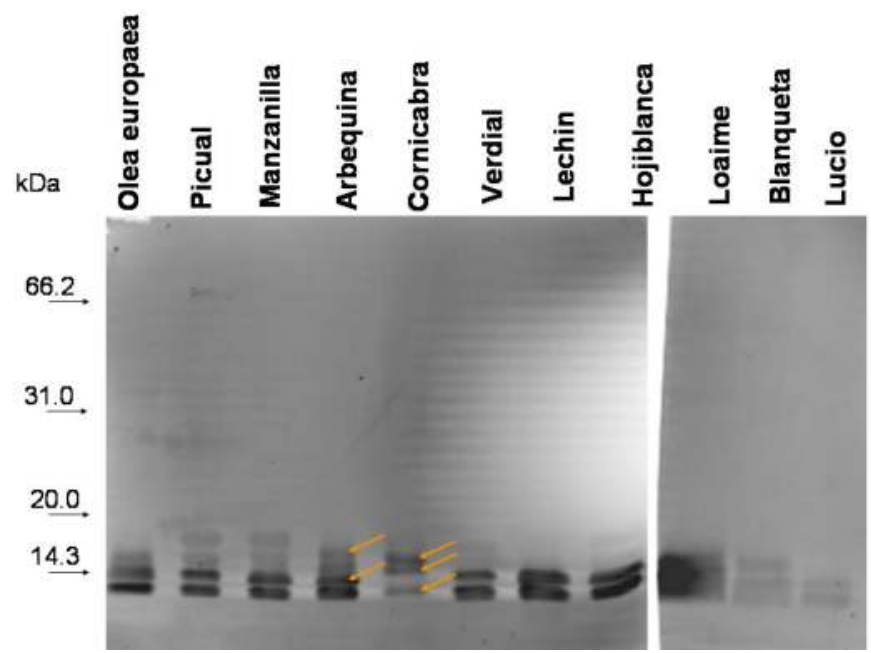

Figure 3. Immunoblot probed with the anti-Ole e 2 polyclonal antiserum. Five major bands were observed (orange arrows), corresponding to apparent molecular weights of 14, 13.7, 14.2, 14.9 and $15.7 \mathrm{kDa}$.

\begin{tabular}{|c|c|c|c|c|c|c|c|c|c|c|c|}
\hline & 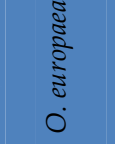 & 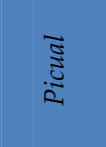 & 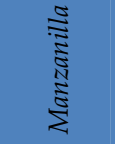 & 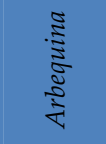 & ن & $\frac{j}{\frac{7}{0}}$ & $\frac{\sqrt{3}}{3}$ & 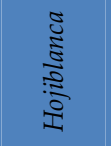 & 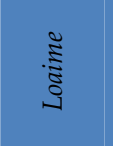 & 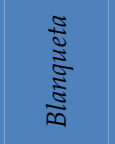 & 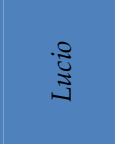 \\
\hline $13.0 \mathrm{kDa}$ & 357152 & 277747 & 248153 & 405554 & 165942 & 394519 & 537187 & 356024 & 910640 & 476889 & 350778 \\
\hline $13.7 \mathrm{kDa}$ & 398025 & 305569 & 261364 & 312528 & $198300^{*}$ & 250846 & 484703 & 463371 & 1004748 & 454397 & 486318 \\
\hline $14.2 \mathrm{kDa}$ & 264210 & $198300^{*}$ & $198300^{*}$ & 223593 & 147305 & $198300^{*}$ & $198300^{*}$ & $198300^{*}$ & 987772 & 410790 & $198300^{*}$ \\
\hline 14.9 kDa & $198300^{*}$ & $198300^{*}$ & $198300^{*}$ & $198300^{*}$ & 290636 & $198300^{*}$ & $198300^{*}$ & $198300^{*}$ & $198300^{*}$ & $198300^{*}$ & $198300^{*}$ \\
\hline $15.7 \mathrm{kDa}$ & $198300^{*}$ & $198300^{*}$ & $198300^{*}$ & 217632 & $198300^{*}$ & $198300^{*}$ & $198300^{*}$ & $198300^{*}$ & $198300^{*}$ & $198300^{*}$ & $198300^{*}$ \\
\hline $\begin{array}{l}\Sigma \text { bands } \\
\text { above }\end{array}$ & 1415987 & 1178216 & 1104417 & 1357607 & 1000483 & 1240265 & 1616790 & 1414295 & 3299760 & 1738676 & 1431996 \\
\hline $\begin{array}{l}\text { Relative } \\
\%\end{array}$ & 42.91 & 35.70 & 33.47 & 41.14 & 30.31 & 37.59 & 49 & 42.86 & 100 & 52.70 & 43.39 \\
\hline $\begin{array}{l}\text { All } \\
\text { bands }\end{array}$ & 2281004 & 2385713 & 2464789 & 2550651 & 249999 & 2472138 & 2437099 & 2312637 & 2913894 & 2092950 & 1973168 \\
\hline $\begin{array}{l}\text { Relative } \\
\%\end{array}$ & 78.3 & 81.87 & 84.59 & 87.53 & 85.80 & 84.84 & 83.64 & 79.37 & 100 & 71.83 & 67.71 \\
\hline $\begin{array}{l}\text { Average } \\
\text { relative } \\
\%\end{array}$ & 60.605 & 58.78 & 59.03 & 64.335 & 58.055 & 61.215 & 66.32 & 61.115 & 100 & 62.265 & 55.55 \\
\hline
\end{tabular}

Table 3. Quantitation of the five major bands cross-reactive to the anti Ole e 2 antibody. Absolute data in volume units $\left(\mathrm{INT}^{*} \mathrm{~mm}^{2}\right) .{ }^{*}$ : band not present. The indicated value corresponds to the average of 5 measurements made in the background. 


\subsection{Immunoblot detection and quantitation of Ole e 5 and Ole e 9}

Immunoblots probed with the commercial antibody to $\mathrm{Cu}, \mathrm{Zn} \mathrm{SOD}$ (Ole e 5) and the polyclonal antiserum to Ole e 9 resulted in the presence of up to five major immunoreactive bands of c.a. 16, 16.5, 22, 26 and $50 \mathrm{kDa}$ for Ole e 5, and two immunoreactive bands of c.a. 36 and $46.5 \mathrm{kDa}$ for Ole e 9 (Figure 4).

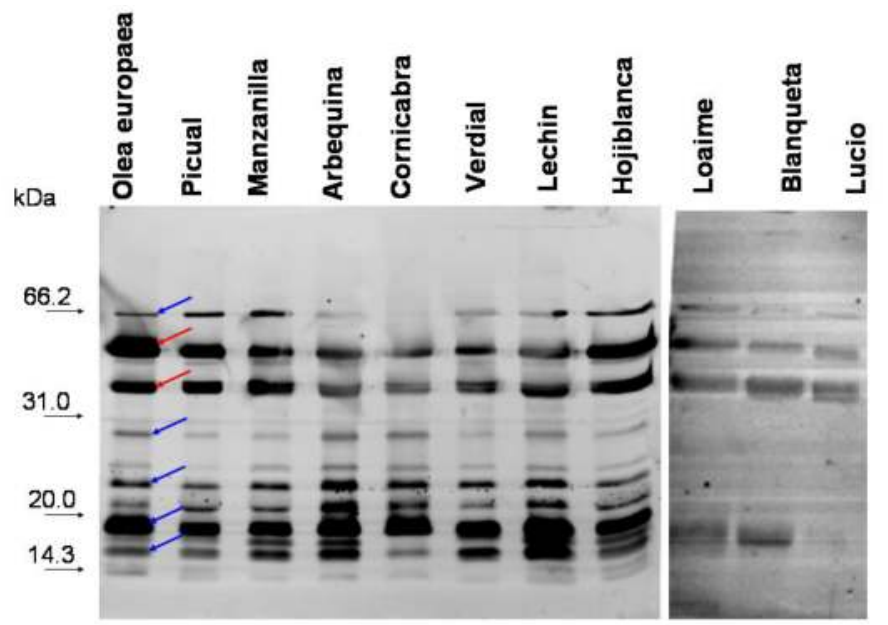

Figure 4. Immunoblot probed with the anti- $\mathrm{Cu}, \mathrm{Zn}-\mathrm{SOD}$ (Ole e 5) commercial antibody and the polyclonal antiserum to Ole e 9. Five major bands were observed (blue arrows), corresponding to apparent molecular weights of 16, 16.5, 22, 26 and $50 \mathrm{kDa}$ for Ole e 5, and two immunoreactive bands of c.a. 36 and $46.5 \mathrm{kDa}$ for Ole e 9 (red arrows).

Bands corresponding to the five Mws of Ole e 5 and two of Ole e 9 were quantitated according to the methods described above. Absolute measurements of the intensity of each individual band and all five bands simultanously are displayed in Tables 4 and 5, as well as the relative percentages calculated as described above.

\section{Clustering of cultivars according to their relative allergenic content}

Table 6 summarizes the final relative averages of reactivity calculated for each cultivar and allergen. Relative values present a wide range in the case of allergens Ole e 1 and Ole e 9, whereas Ole e 2 and Ole e 5 allergens maintain values relatively constant, higher than $50 \%$ for all cultivars, with a single exception (Ole e 5 in the cultivar 'Lucio').

Therefore, the following thresholds have been defined in order to divide cultivars into cultivars with high/average/low allergenic content for the allergens Ole e 1 and Ole e 9. In the case of Ole e 1, we have considered that percentages of $30 \%$ and $35 \%$ may represent reasonable limits, taking into account the extremely high content of some cultivars in this allergen, which may represents up to $23 \%$ of the total protein content for these cultivars (Castro et al. 2003). For Ole e 9 , the percentages of $40 \%$ and $60 \%$ were selected as the thresholds. 


\begin{tabular}{|c|c|c|c|c|c|c|c|c|c|c|c|}
\hline & 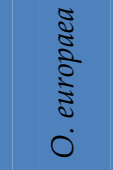 & 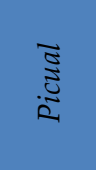 & 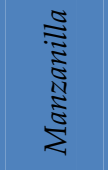 & $\frac{\sqrt{1}}{\frac{7}{5}}$ & $\frac{0}{0}$ & 竎 & $\frac{\sqrt{3}}{\sqrt[3]{3}}$ & 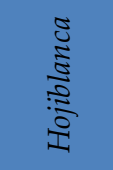 & 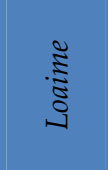 & $\begin{array}{c}\frac{\sigma}{\tilde{\Xi}} \\
\frac{a}{5} \\
\frac{a}{\infty}\end{array}$ & 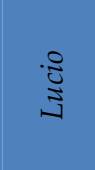 \\
\hline $16.0 \mathrm{kDa}$ & 12522 & 10472 & 13810 & 16174 & 8515 & 16875 & 20320 & 19682 & 1054 & 793 & 714 \\
\hline $16.5 \mathrm{kDa}$ & 33503 & 21491 & 23191 & 27710 & 33630 & 28904 & 36422 & 39682 & 27218 & 23811 & 4304 \\
\hline $22.0 \mathrm{kDa}$ & 9451 & 7946 & 9623 & 14385 & 12453 & 9703 & 13812 & 17211 & 6380 & 5201 & 5041 \\
\hline $26.0 \mathrm{kDa}$ & 6221 & 3389 & 3688 & 7134 & 7617 & 4447 & 7775 & 11424 & 12698 & 9191 & 7098 \\
\hline $50.0 \mathrm{kDa}$ & 5611 & 7474 & 9643 & 4818 & 3941 & 5794 & 8238 & 19507 & 12979 & 5625 & 4200 \\
\hline $\begin{array}{l}\Sigma \text { bands } \\
\text { above }\end{array}$ & 67308 & 50772 & 59955 & 70221 & 66156 & 65723 & 86567 & 107506 & 47350 & 44621 & 21357 \\
\hline Relative \% & 62.61 & 47.23 & 55.77 & 65.32 & 61.54 & 61.13 & 80.52 & 100 & 44.04 & 41.51 & 19.87 \\
\hline All bands & 122909 & 95529 & 107694 & 136847 & 128879 & 118503 & 157103 & 155113 & 136354 & 107779 & 79135 \\
\hline Relative \% & 78.23 & 60.81 & 68.55 & 87.11 & 82.03 & 75.43 & 100 & 98.73 & 86.79 & 68.60 & 50.37 \\
\hline $\begin{array}{l}\text { Average } \\
\text { relative \% }\end{array}$ & 70.42 & 54.02 & 62.16 & 76.215 & 71.785 & 68.28 & 90.26 & 99.365 & 65.415 & 55.055 & 35.12 \\
\hline $\begin{array}{l}\text { Average } \\
\text { relative to } \\
100 \%\end{array}$ & 70.87 & 54.36 & 62.55 & 76.70 & 72.24 & 68.72 & 90.83 & 100 & 65.83 & 55.41 & 35.34 \\
\hline
\end{tabular}

Table 4. Quantitation of the five major bands cross-reactive to the anti $\mathrm{Cu}, \mathrm{Zn}$ SOD (Ole e 5) antibody. Absolute data in volume units $\left(\mathrm{INT}^{*} \mathrm{~mm}^{2}\right.$ ). In this case, the average relative percentage was again referred to $100 \%$, as the maximun relative percentages previously calculated corresponded to two different cultivars ('Hojiblanca' and 'Lechín').

\begin{tabular}{|c|c|c|c|c|c|c|c|c|c|c|c|}
\hline & 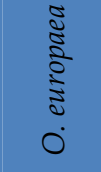 & 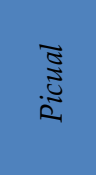 & 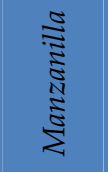 & 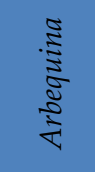 & 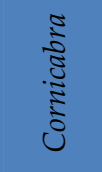 & $\begin{array}{c}\frac{j}{3} \\
\frac{9}{3} \\
\overline{3} \\
\end{array}$ & 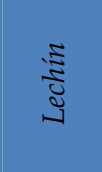 & 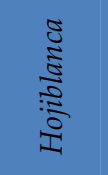 & $\underset{\Xi}{\Xi}$ & $\begin{array}{l}\frac{\Xi}{0} \\
\frac{a}{a} \\
\frac{\Xi}{\infty}\end{array}$ & 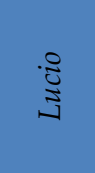 \\
\hline 36 kDa & 20241 & 18902 & 25868 & 18912 & 15583 & 17605 & 24746 & 44273 & 29766 & 28377 & 20736 \\
\hline $46.5 \mathrm{kDa}$ & 39567 & 23419 & 17751 & 16764 & 13584 & 13916 & 20517 & 53338 & 22784 & 13160 & 12730 \\
\hline $\begin{array}{l}\Sigma 36 \text { and } \\
46.5 \mathrm{kDa}\end{array}$ & 59808 & 42322 & 43619 & 35677 & 29167 & 31521 & 45264 & 97612 & 52550 & 41538 & 33467 \\
\hline Relative \% & 61.27 & 43.36 & 44.68 & 36.55 & 29.88 & 32.29 & 46.37 & 100 & 53.83 & 42.55 & 34.28 \\
\hline $\begin{array}{l}36 \text { and } 46.5 \\
k D a\end{array}$ & 72676 & 51950 & 56389 & 47169 & 39589 & 45075 & 59672 & 102195 & 74531 & 52213 & 39717 \\
\hline Relative \% & 71.11 & 50.83 & 55.17 & 46.15 & 38.73 & 44.10 & 58.39 & 100 & 72.93 & 51.09 & 38.86 \\
\hline \begin{tabular}{|l} 
Average \\
relative \%
\end{tabular} & 66.19 & 47.095 & 49.925 & 41.35 & 34.305 & 38.195 & 52.38 & 100 & 63.38 & 46.82 & 36.57 \\
\hline
\end{tabular}

Table 5. Quantitation of the two major bands cross-reactive to the anti Ole e 9 antibody. Absolute data in volume units $\left(\mathrm{INT}^{*} \mathrm{~mm}^{2}\right)$. 


\begin{tabular}{|c|c|c|c|c|c|c|c|c|c|c|c|c|}
\hline & $\begin{array}{c}\tilde{\Xi} \\
\tilde{\Xi} \\
0 \\
\vdots \\
\vdots \\
0 \\
0\end{array}$ & $\underset{\vec{s}}{\vec{s}}$ & 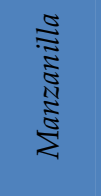 & 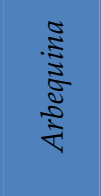 & $\begin{array}{l}0 \\
\frac{0}{0} \\
\frac{0}{0} \\
0\end{array}$ & $\begin{array}{l}\overline{7} \\
\overline{0} \\
\overline{0} \\
\overline{0}\end{array}$ & $\frac{\tilde{z}}{\tilde{\Xi}}$ & $\begin{array}{l}0 \\
\frac{5}{5} \\
\frac{5}{0} \\
\frac{\pi}{5}\end{array}$ & 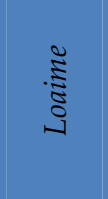 & 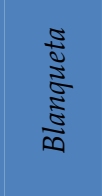 & $\begin{array}{c}3 \\
3 \\
3 \\
-1\end{array}$ & 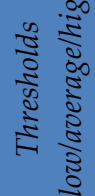 \\
\hline Ole e 1 & 8.62 & 35.21 & 39.17 & 28.5 & 41.88 & 24.68 & 42.125 & 72.68 & 83.915 & 100 & 41.39 & $\begin{array}{c}30 \%- \\
35 \%\end{array}$ \\
\hline Ole e 2 & 60.605 & 58.78 & 59.03 & 64.335 & 58.055 & 61.215 & 66.32 & 61.115 & 100 & 62.265 & 55.55 & - \\
\hline Ole e 5 & 70.87 & 54.36 & 62.55 & 76.70 & 72.24 & 68.72 & 90.83 & 100 & 65.83 & 55.41 & 35.34 & - \\
\hline Ole e 9 & 66.19 & 47.095 & 49.925 & 41.35 & 34.305 & 38.195 & 52.38 & 100 & 63.38 & 46.82 & 36.57 & $\begin{array}{l}40 \%- \\
60 \%\end{array}$ \\
\hline
\end{tabular}

Table 6. Abstract of the relative percentages of reactivity corresponding to the cultivars analysed for each allergen. High reactivity is marked by using bold text, and low reactivity is marked by italics, after considering the thresholds indicated.

The following categories were established after following the above mentioned criteria:

- $\quad$ 'Hojiblanca'-type extract, characterized by high contents of Ole e 1 and Ole e 9. The cultivar 'Loaime' could be included in this same group.

- $\quad$ 'Picual'- type extract, characterized by high content of Ole e 1 and low to average contents of Ole e 9. The cultivars 'Manzanilla', 'Lucio', 'Cornicabra', 'Lechín' and 'Blanqueta' could be included in this same group.

- $\quad$ 'Arbequina' -type extract, characterized by low content in both Ole e 1 and Ole e 9, with average to high contents of Ole e 5 and Ole e 2. The cultivar 'Verdial' could be included in this same group.

The Olea europaea commercial extract doesn't match any of the tested cultivars, corresponding to an extract with a relative high proportion of Ole e 9 and low proportion of Ole e 1 .

This initial proposal should be implemented by further analyzing additional olive pollen allergens (some of them highly relevant from a clinical point of view like Ole e 7), and by analyzing the allergen profiles of other agronomically relevant cultivars. However, the classification obtained here is in good agreement with the genetic relationships among cultivars already described on the basis of Ole e 1 and Ole e 2 polymorphism (HammanKhalifa et al. 2008; Jiménez-López et al., 2012). Moreover, this classification also supports clinical findings describing sharp differences in patient's reactivity to commercially available extracts depending on their place of residence in Spain, where these model cultivars are differentially predominant (Casanovas et al. 1997). Providing that sensitization to specific allergens can be determined in individual patients, the application of the concept of allergenic profile to allergen extracts could be considered a major adventage. This concept would therefore open the posibility of choosing the allergen extract matching the sensitivity of each patient. Moreover, the continuous development of new molecular tools (e.g. new 
antibodies with higher specificity) will undoubtedly improve the present type of studies, which has to be considered still preliminary.

\section{Acknowledgements}

This work was supported by the Spanish Ministry of Science and Innovation (MICINN) (ERDF-cofinanced projects AGL2008-00517, BFU2011-22779 and PIE-200840I186) and the Junta de Andalucía (ERDF-cofinanced projects P2010-CVI5767 and P2010-AGR6274). The authors acknowledge the availability of plant material and the collaboration of the staff of the IFAPA center "Venta del Llano" (Mengíbar, Spain) depending from the Andalusian Regional Government.

\section{Author details}

Sonia Morales, Antonio Jesús Castro, Carmen Salmerón, María Isabel Rodríguez-García and Juan de Dios Alché Estación Experimental del Zaidín (CSIC), Granada, Spain

Francisco Manuel Marco

RED Inmunal S.A.U. Tecnoalcalá, Alcalá de Henares, Madrid, Spain

Sonia Morales

Proteomic Research Service, Hospital Universitario San Cecilio, Granada, Spain

\section{References}

Alché, J.D., Castro, A.J., Jiménez-López, J.C., Morales, S., Zafra, A., Hamman-Khalifa, A.M. \& Rodríguez-García, M.I. (2007). Differential characteristics of olive pollen from different cultivars: biological and clinical implications. Journal of Investigational Allergology \& Clinical Immunology, Vol. 17, Suppl 1., pp. 63-68, ISSN 1018-9068

Alché, J.D., Castro, A.J., Olmedilla, A., Fernández, M.C., Rodríguez, R., Villalba, M. \& Rodríguez-García, M.I. (1999). The major olive pollen allergen (Ole e I) shows both gametophytic and sporophytic expression during anther development, and its synthesis and storage takes place in the RER. Journal of Cell Science, Vol. 112, No. 15, pp. 25012509, ISSN 0021-9533

Alché, J.D., Cismondi, I.D., Castro, A.J., Hamman Khalifa, A., \& Rodríguez García, M.I. (2003). Temporal and spatial gene expression of Ole e 3 allergen in olive (Olea europaea L.) pollen. Acta Biologica Cracoviensia, Series Botanica, Vol. 45, No. 1, pp. 89-95, ISSN 00015296

Alché, J.D., Corpas, F., Rodríguez-García, M.I., \& del Río, L.A. (1998). Identification and immunolocalization of superoxide dismutase isoenzymes of olive pollen. Physiologia Plantarum, Vol. 104, No. 4, pp. 772-776, ISSN 1399-3054

Alché, J.D., M'rani-Alaoui, M., Castro, A.J., \& Rodríguez-García, M.I. (2004). Ole e 1, the major allergen from olive (Olea europaea L.) pollen, increases its expression and is 
released to the culture medium during in vitro germination. Plant $\mathcal{E}$ Cell Physiology, Vol. 45, No. 9, pp. 1149-1157, ISSN 0032-0781

Alché, J.D., Rodríguez-García, M.I., Castro, A.J., \& Alché, V. (2005). Kit para el diagnóstico de hipersensibilidad frente a alergenos del polen del olivo y su utilización. Spanish Office for Patents Bulletin (OEPM). Publication reference 2196952.

Alché, J.D., Rodríguez-García, M.I., Castro, A.J., \& Alché, V. (2010). Perfeccionamientos introducidos en el objeto de solicitud de patente española № P200100995. Spanish Office for Patents Bulletin (OEPM). Publication reference 2326399.

Asturias, J.A., Arilla, M.C., Gómez-Bayon, N., Martínez, J., Martínez, A., \& Palacios, R. (1997). Cloning and expression of the panallergen profilin and the major allergen (Ole e 1) from olive tree pollen. Journal of Allergy \& Clinical Immunology, Vol. 100, No. 3, pp. 365-372, ISSN 0091-6749

Barranco, D., Trujillo, I., \& Rallo, L. (2005). Libro I. Elaiografía Hispánica. In: Variedades del olivo en España. Rallo, L., Barranco, D., Caballero, J.M., Del Río, C., Martín, A., Tous, J., \& Trujillo, I. (Eds.) Madrid: Junta de Andalucía, MAPA and Ediciones Mundi-prensa.

Carnés Sánchez, J., Iraola, V.M., Sastre, J., Florido, F., Boluda, L., \& Fernández-Caldas, E. (2002). Allergenicity and immunochemical characterization of six varieties of Olea europaea. Allergy, Vol. 57, No. 4, pp. 313-318, ISSN 0105-4538

Casanovas, M., Florido, F., Sáenz de San Pedro, B., González, P., Martínez-Alzamora, F., Marañón, F., \& Fernández-Caldas, E. (1977). Sensitization to Olea europaea: geographical differences and discrepancies. Allergologia et Immunopathologia (Madrid), Vol. 25, No. 4, pp. 159-166

Castro, A.J., Alché, J.D., Cuevas, J., Romero, P.J., Alché, V., \& Rodríguez-García, M.I. (2003). Pollen from different olive tree cultivars contains varying amounts of the major allergen Ole e 1. International Archives of Allergy \& Immunology, Vol. 131, No. 3, pp. 164-173, ISSN 1018-2438

Castro, A.J., Bednarczyk, A., Schaeffer-Reiss, C., Rodríguez-García, M.I. Van Dorsselaer, A., \& Alché, J.D. (2010). Screening of Ole e 1 polymorphism among olive cultivars by peptide mapping and N-glycopeptide analysis. Proteomics, Vol. 10, pp. 953-962, ISSN 1615-9861

Conde Hernández, J., Conde Hernández, P., González Quevedo Tejerina, M.T., Conde Alcañiz, M.A., Conde Alcañiz, E.M., Crespo Moreira, P., \& Cabanillas Platero, M. (2002). Antigenic and allergenic differences between 16 different cultivars of Olea europaea. Allergy, Vol. 57 Suppl. 71, pp. 60-65, ISSN 0105-4538

Duffort, O., Palomares, O., Lombardero, M., Villalba, M., Barber, D., Rodríguez, R., \& Polo, F. (2006). Variability of Ole e 9 Allergen in Olive Pollen Extracts: Relevance of Minor Allergens in Immunotherapy Treatments. International Archives of Allergy \& Immunology, Vol. 140, No. 2, pp. 131-138, ISSN 1018-2438

Fernández-Caldas, E., Carnés, J., Iraola, V., \& Casanovas, M. (2007). Comparison of the allergenicity and Ole e 1 content of 6 varieties of Olea euroapea pollen collected during 5 consecutive years. Annals of Allergy, Asthma \& Immunology, Vol. 98, No. 5, pp. 464-470, ISSN 1081-1206 
Geller-Bernstein, C., Arad, G., Keynan, N., Lahoz, C., Cardaba, B., \& Waisel, Y. (1996). Hypersensitivity to pollen of Olea europaea in Israel. Allergy, Vol. 51, No. 5, pp. 356-359, ISSN 0105-4538

Hamman-Khalifa, A.M. (2005). Utilización de marcadores relacionados con la alergenicidad y la biosíntesis de lípidos para la discriminación entre cultivares de olivo. Ph.D. report. University of Granada. Spain.

Hamman-Khalifa, A.M., Alché, J.D., \& Rodríguez-García, M.I. (2003). Discriminación molecular en el polen de variedades españolas y marroquíes de olivo (Olea europaea L.). Polen, Vol. 13, pp. 219-225, ISSN 1135-8408

Hamman Khalifa, A.M., Castro, A.J., Rodríguez García, M.I., \& Alché, J.D (2008). Olive cultivar origin is a major cause of polymorphism for Ole e 1 pollen allergen. BMC Plant Biology, Vol. 8, pp. 10, ISSN 1471-2229

Huecas, S., Villalba, M., \& Rodríguez, R. (2001). Ole e 9, a major olive pollen allergen is a 1,3beta-glucanase. Isolation, characterization, amino acid sequence, and tissue specificity. Journal of Biological Chemistry, Vol. 276, No. 30, pp. 27959-27966, ISSN 0021-9258

Jiménez-López, J.C. (2008). Caracterización molecular del polimorfismo de las profilinas en el polen del olivo y otras especies alergogénicas. Ph. D. report. University of Granada. Spain.

Jiménez-López, J.C., Morales, S., Castro, A.J., Volkmann, D., Rodríguez-García, M.I. \& Alché, J.D. (2012). Characterization of profilin polymorphism in pollen with a focus on multifunctionality. PLoS One, Vol. 7, No. 2, p. e30878, ISSN 1932-6203

Lauzurica, P., Gurbindo, C., Maruri, N., Galocha, B., Díaz, R., González, J., García, R. \& Lahoz, C. (1988). Olive (Olea europaea) pollen allergens. I. Immunochemical characterization by immunoblotting, CRIE and immunodetection by a monoclonal antibody. Molecular Immunology, Vol. 25, pp. 329-335, ISSN 0161-5890

Liccardi, G., D'Amato, M., \& D'Amato, G. (1996). Oleaceae pollinosis: a review. International Archives of Allergy E Immunology, Vol. 111, No. 3, pp. 210-217, ISSN 1018-2438

Lombardero, M., Barbas, J.A., Moscoso del Prado, J., \& Carreira J. (1994). cDNA sequence analysis of the main olive allergen, Ole e I. Clinical \& Experimental Allergy, Vol. 24, No. 8, pp. 765-770, ISSN 1365-2222

Martínez, A., Asturias, J.A., Monteseirín, J., Moreno, V., García-Cubillana, A., Hernández, M., de la Calle, A., Sánchez-Hernández, C., Pérez-Formoso, J.L., \& Conde, J. (2002). The allergenic relevance of profilin (Ole e 2) from Olea europaea pollen. Allergy, Vol. 57, Suppl. 71, pp. 17-23, ISSN 0105-4538

Morales, S., Castro, A.J., Jiménez-López, J.C., Florido, F., Rodríguez-García, M.I., \& Alché J.D. (2012). A novel multiplex method for the simultaneous detection and relative quantification of pollen allergens. Electrophoresis, Vol. 33, pp. 1-8, DOI 10.1002/elps.201100667, ISSN: 1522-2683

Morales, S., Jiménez-López, J.C., Castro, A.J., Rodríguez-García, M.I., \& Alché, J.D. (2008). Olive pollen profilin (Ole e 2 allergen) co-localizes with highly active areas of the actin cytoskeleton and is released to the culture medium during in vitro pollen germination. Journal of Microscopy-Oxford, Vol. 231, No. 2, pp. 332-341, ISSN 1365-2818 
Tejera, M.L., Villalba, M., Batanero, E., \& Rodríguez, R. (1999). Identification, isolation, and characterization of Ole e 7, a new allergen of olive tree pollen. The Journal of Allergy $\mathcal{E}$ Clinical Immunology, Vol. 104, No. 4, pp. 797-802, ISSN 0091-6749

Villalba, M., Batanero, E., Lopez-Otín, C., Sánchez, L.M., Monsalve, R.I., González de la Peña, M.A., Lahoz, C., \& Rodríguez, R. (1993). The amino acid sequence of Ole e I, the major allergen from olive tree (Olea europaea) pollen. European Journal of Biochemistry, Vol. 216, No. 3, pp. 863-869, ISSN 0014-2956

Villalba, M., Batanero, E., Monsalve, R.I., González de la Peña, M.A. Lahoz, C., \& Rodríguez, R. (1994). Cloning and expression of Ole e I, the major allergen from olive tree pollen. Polymorphism analysis and tissue specificity. Journal of Biological Chemistry, Vol. 269, No. 21, pp. 15217-15222, ISSN 0021-9258

Wheeler, A.W. (1992). Hypersensitivity to the allergens of the pollen from the olive tree (Olea europaea). Clinical and Experimental Allergy, Vol. 22, No. 12, pp. 1052-1057, ISSN $1365-2222$

Zafra, A. (2007). Caracterización preliminar del polimorfismo de la proteína alergénica Ole e 5 en el polen del olivo de distintos cultivares. Master Thesis. University of Granada. Spain. 